\title{
Can Brazil Become a Green Hydrogen Powerhouse?
}

\author{
Rafael Kelman1, Luana de S. Gaspar¹, Florian S. Geyer², Luiz A. N. Barroso1,3, Mario V. F. Pereira1 \\ ${ }^{1}$ PSR-Energy Consulting and Analytics, Rio de Janeiro, Brazil \\ ${ }^{2}$ Consultant of Renewable Energy and Green Hydrogen, MSc/VU Amsterdam and MBA in Renewables/Beuth University, Berlin, \\ Germany \\ ${ }^{3}$ Instituto de Investigación Tecnológica, ICAI, Universidad Pontificia Comillas, Madrid, España \\ Email: rafael@psr-inc.com, luana@psr-inc.com, fgeyer@posteo.de, luiz@psr-inc.com, mario@psr-inc.com
}

How to cite this paper: Kelman, R., Gaspar, L. de S., Geyer, F.S., Barroso, L.A.N. and Pereira, M.V.F. (2020) Can Brazil Become a Green Hydrogen Powerhouse? Journal of Power and Energy Engineering, 8, 21-32.

https://doi.org/10.4236/jpee.2020.811003

Received: October 29, 2020

Accepted: November 27, 2020

Published: November 30, 2020

Copyright $\odot 2020$ by author(s) and Scientific Research Publishing Inc. This work is licensed under the Creative Commons Attribution International License (CC BY 4.0).

http://creativecommons.org/licenses/by/4.0/

\begin{abstract}
This paper assesses the feasibility of green hydrogen production in Brazil. By green hydrogen, it is meant the hydrogen produced by the electrolysis of water by consuming electricity produced by renewable sources. The country has large areas with high solar irradiation and favorable wind velocities that help to make wind power and solar PV economical alternatives. Other factors include lower investments and lower grid integration cost with respect to global average, because of the large share of hydropower. As known, hydro plants respond well to the short-term variability of renewable production. Local regulations also incentivize renewable energy. For example, it is possible, according to market rules, for a hydrogen producer to sign a financial Power Purchase Agreement (PPA) contract with a producer or trader to secure a firm, renewable energy supply for the electrolysis process. This market-driven factor, and other key factors, such as low price of electricity, are considered in an economic feasibility model. Results from this model suggest that Brazil could become a green hydrogen powerhouse for the internal market and potential exports to Germany and other European countries.
\end{abstract}

\section{Keywords}

Green Hydrogen, Strategy, Brazil, Export

\section{Introduction}

In July 2020, the European Union (EU) released its Hydrogen Strategy, acknowledging the importance of hydrogen $\left(\mathrm{H}_{2}\right)$ to meet its international obligations under the Paris Agreement. This strategy describes three phases that are needed to speed up the deployment of a hydrogen market in Europe until 2050. 
In each phase, it is considered an increase in installed electrolyser capacity for green hydrogen production and a further insertion of this technology in hardto-decarbonize sectors of the economy [1]. Countries outside Europe, such as Japan and Australia are pursuing similar objectives [2].

The Communication of the European Commission (COM, 2020) 301 of July 2020 [1] states the following:

There are many reasons why hydrogen is a key priority to achieve the European Green Deal and Europe's clean energy transition. Renewable electricity is expected to decarbonize a large share of the EU energy consumption by 2050, but not all of it. Hydrogen has a strong potential to bridge some of this gap, as a vector for renewable energy storage, alongside batteries, and transport, ensuring back up for seasonal variations and connecting production locations to more distant demand centers. In its strategic vision for a climate-neutral EU published in November 2018, the share of hydrogen in Europe's energy mix is projected to grow from the current less than $2 \%$ to $13 \%-14 \%$ by 2050.

...Almost all Member States have included plans for clean hydrogen in their National Energy and Climate Plans, 26 have signed up to the "Hydrogen Initiative", and 14 Member States have included hydrogen in the context of their alternative fuels infrastructure national policy frameworks. Some have already adopted national strategies or are in the process of adopting one.

Germany has announced an incentive of 9 billion euros for the development of its hydrogen project. One of the goals of this strategy is to incentivize the development of a domestic market for hydrogen, which is expected to reach about 90 or 110 TWh of hydrogen consumption until 2030. This is almost twice as much as the current consumption of hydrogen in Germany, which accounts for 55 TWh. Of this consumption, only 3.85 TWh are currently produced by electrolysis and the great majority comes from the steam reform of natural gas [3].

To meet the expected future demand, an additional $5 \mathrm{GW}$ of electrolyser capacity will be built in Germany, representing 14 TWh of green hydrogen production. However, that will not be enough to cover all new demand, which will need to be met by imports. Therefore, Germany plans to build up and intensify international cooperation and direct 2 billion euros of the previously mentioned incentive to produce hydrogen abroad. The partner countries will be analyzed in terms of availability of renewable energy and water resources, cost-efficiency of hydrogen production, energy infrastructure and demand, availability of land for hydrogen production, and social and socio-political framework [3].

This need for imports will also be shared by other countries in the European Union [1]. In this scenario, Brazil could be a viable candidate to be a major supplier of hydrogen for Europe. The present article discusses this possibility, describing possible advantages that Brazil may have in this global hydrogen market.

This work is organized as follows. In Section 2, a brief overview of the current Brazilian electrical system is provided, focusing on renewable energy sources. 
Section 3 details the possible arrangements that a green hydrogen producer could make to ensure a clean electricity supply. Section 4 provides a preliminary feasibility analysis of the possible production of hydrogen in Brazil. Additional factors that could provide an advantage to the country in this market are shown in Section 5, and finally some concluding remarks are addressed in Section 6.

\section{The Brazilian Case}

Brazil has a surface area of 8.5 million $\mathrm{km}^{2}$, equivalent to continental USA and half of Alaska, and a population size of 211 million inhabitants [4]. Electricity consumption in 2019 was 545 TWh and total installed capacity exceeded 170 GW. The power matrix has a high insertion of renewables, that accounted for $83 \%$ of all domestic electricity supplied (Figure 1) in 2019 with hydropower being the main source, with more than $100 \mathrm{GW}$ of installed capacity. The share of sugar cane biomass is also significant, as well as wind and solar power, that have been experiencing large growth rates (15\% and 92\%, respectively, between 2018 and 2019 for these sources) [5].

Brazil's hydro reservoirs and the countrywide transmission grid are used to modulate the seasonal production of biomass and the fluctuations of wind and solar power. The system reservoirs are used as "energy warehouses" that can supply electricity to the system when there is a smaller generation with wind, sun and sugarcane, since large reservoirs in cascade can be operated with relatively high flexibility. A single integrated grid also supports the portfolio effect observed by the combination of various sources of power production dispersed in such a large area. The high voltage grid (above $130 \mathrm{kV}$ ) has 140 thousand $\mathrm{km}$ of lines.

The observed growth of variable renewable energy (VRE) sources is due mainly to its highly competitive costs, representing nowadays the cheapest resources in Brazil [6]. For this reason, large amounts of solar photovoltaic (PV) and wind power have been contracted through auctions. About 15,000 MW of

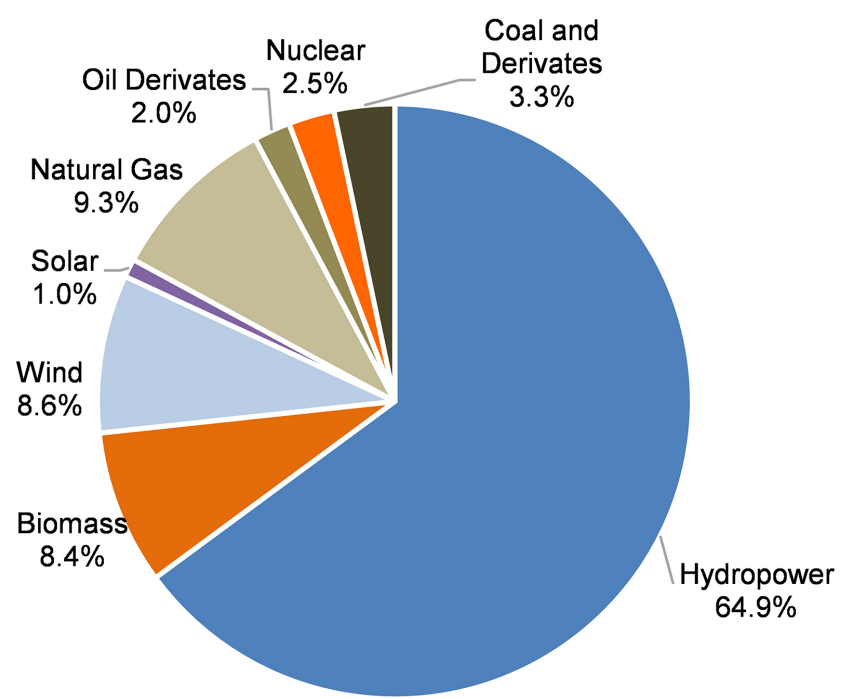

Figure 1. Brazilian domestic electricity supply by source [5]. 
wind and $4400 \mathrm{MW}$ of solar power were contracted since 2010 and the auctions that took place in 2019 had an average energy price of respectively $18 \mathrm{USD} / \mathrm{MWh}$ and 15 USD/MWh, considering an exchange rate of 5.6 BRL/USD [6].

Given the country's dimensions and available natural resources, there is a huge potential for further development of VRE. Brazil ranks \#3 in Bloomberg's Climatescope 2019. It attracted nearly $\$ 60$ billion (by far the largest in Latin America) in new asset finance for clean energy plants in 2009-2018, with more than half of this amount due to wind power and nearly a fifth due to solar power [7].

A few reasons explain why prices for VRE sources are low in Brazil:

1) Resources: capacity factors of wind power projects in Brazil tend to be high ( $45 \%$ for the entire year, exceeding $70 \%$ in windier months). This is at least $50 \%$ higher than the global average (less than 30\%) [8]. Solar PV with widespread use of 1-axis tracker is also competitive, because additional costs are more than compensated by the value of the increase in energy production. There is also a huge expansion potential for VRE installed capacity given the extensive areas of good resource and cheap land.

2) Synergies: two other aspects are also beneficial to the economic development of VRE in Brazil: a) the seasonal complementarity between wind and hydropower, as wind power production increases during the dry season (Figure $2(\mathrm{a}))$; b) the existence of regions that simultaneously offer good conditions for wind power (i.e. high wind speeds with smaller variability) and solar PV (good irradiation). Furthermore, wind power tends to increase at night when solar PV power is idle (Figure 2(b)). These aspects reduce the integration costs of VRE to the grid.

3) Flexibility: VRE benefits from existing flexible resources in the system that adequately mitigates short term production variability and provide balancing services at competitive costs, such as hydro and thermal power. Brazil has over 100 GW of hydropower, a fast response resource, that accounted for $70.4 \%$ of total electricity production in 2019 [9]. Reservoirs of hydro power plants store energy that can offset short and mid-term intermittencies of VRE production (Figure 3 ).

4) Single National Grid: the existence of a single interconnected grid provides massive power transfers between regions. A robust transmission network leverages synergic and flexibility gains from different hydrologic patterns of a country with continental dimensions such as Brazil and different potentials for wind and solar power generation as well.

\section{Demand-Side Factors}

A possible production of green hydrogen in Brazil could benefit not only from the previously mentioned flexible and cheap renewable resources, but also from incentives in contracting these "clean" sources and benefits in case of self-production of electricity. Careful considerations of local power sector regulations, which incentivizes renewable generation and self-production of electricity, are important when studying detailed feasibility. 


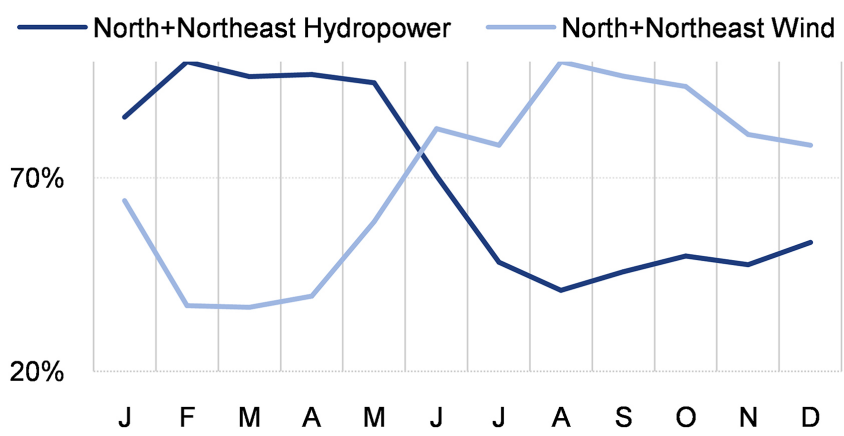

(a)

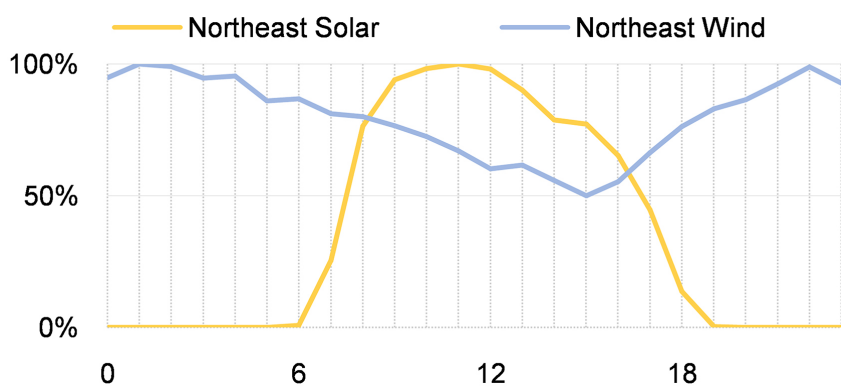

(b)

Figure 2. (a) Seasonal and (b) hourly complementarity between renewable sources. Data from [9].

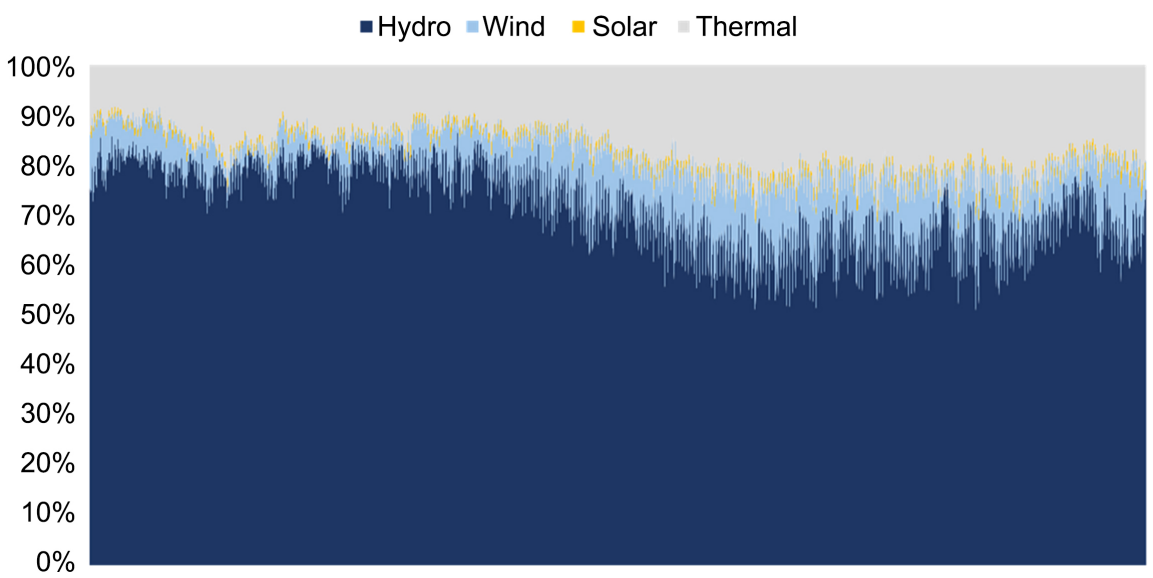

Figure 3. Hourly electricity production by source in Brazil. Data from [9].

Power needed for hydrogen production can be supplied by two arrangements:

1) Green $\mathrm{H}_{2}$ producer develops, builds, and operates wind/solar projects to self-produce electricity.

2) Green $\mathrm{H}_{2}$ producer signs an energy supply contract with developer/trader that grants the right over electricity produced by developer/trader of wind/solar projects. This happens even if physically the demand is connected to the grid in point A and the supply (wind/solar projects) is in point B. In this case there are two possibilities: a) electrolyser "rents" projects from a seller (either supplier or trader) and is characterized as a self-producer; b) electrolyser signs standard Power Purchase Agreement (PPA) with producer. 
In both cases involving a contract, the energy developer/trader may be requested to ensure firm supply to the electrolyser, which implicates that the seller should price the production variability risk and the need to purchase shortfalls between production and contracted volumes in the short-term market. For instance, a seller may include "backup" energy from hydropower purchased from a third-party and delivered to the electrolyser.

The benefit of a PPA is that it enables investments in new renewable generation capacity, since it provides certainty of a long-term revenue, reducing the risks associated with electricity sales. That way it is also possible to track the source of the electricity, ensuring that it is produced according to sustainability criteria.

Large consumers of electricity, such as mining company Vale [10], have been contracting electricity with developers of renewable energy in this fashion. This arrangement has been categorized by regulator as a means of self-production, providing economic advantages to the demand while transferring project development, construction, and $\mathrm{O} \& \mathrm{M}$ to the party with this expertise.

A feasibility model would need to consider the financial structure of the project with more details as well as other critical factors, such as:

- Logistics for the export of hydrogen-carrier.

- Local incentives and taxes.

- Connection of the electrolyser to the grid to assure no bottlenecks exist for its supply.

- Transmission tariff, which has a locational component in Brazil that is important.

- Commercial model and premium for firmness of renewable energy.

The last three factors will only be considered in the second scenario, with an energy supply contract.

\section{Preliminary Feasibility Analysis}

A portfolio of competitive solar PV + wind power can be negotiated between an electrolyser demand and a supplier either directly or through a trader. The trader also includes backup of renewable power to provide a firm load to the electrolyser that is fully renewable. Altogether the company PSR-Energy Consulting and Analytics estimates that such firm load supplied $100 \%$ by renewable electricity would be priced around US\$ 30 - 35 per MWh considering regulations and incentives.

Besides the electricity cost, the production costs of green hydrogen also depend upon the electrolyser's investment cost and its load factor [11]. Whereas the electrolyser's CAPEX depends mostly on the scale up of its production and on technological advances that are dictated mostly by the global market, the electricity and load factors are "local" and, as previously commented, provide an advantage for Brazil, given its competitive price for renewable electricity and a high load factor of electrolyser usage. 
A financial model was built to evaluate the cost of green $\mathrm{H}_{2}$ production in the country as a function of 1 ) investment cost for the electrolyser; 2) yearly plant $\mathrm{O}$ $\& M$ cost; 3) unit price of renewable electricity efficiently procured with producers or traders; 4) efficiency of electrolysis, expressed as $\mathrm{kg}$ of produced $\mathrm{H}_{2}$ per MWh of electricity; 5) economic data, such as discount rate and project lifetime; 6) the number of operation hours per year of the electrolyser (or, equivalently, plant factor).

A conservative analysis made by PSR using this financial model showed an estimate of US\$ 2.5 per $\mathrm{kg} \mathrm{H}_{2}$, considering electrolyser/BOS cost of $750 \mathrm{US} \$ / \mathrm{kW}$ and electricity price of 3 cents USD per $\mathrm{kWh}$. This estimative was calculated considering a electrolyser capacity of $1 \mathrm{~kW}$, a lifetime of 10 years, an yearly OPEX of $2 \%$ of the total CAPEX, an efficiency of $19 \mathrm{~kg}$ of $\mathrm{H}_{2} / \mathrm{MWh}$, a discount rate of $10 \%$ and a load factor of $92 \%$.

The calculation of hydrogen production cost $(\$ / \mathrm{kg})$ considers the sum of annual costs for green hydrogen production $(\$ / \mathrm{kW} \cdot \mathrm{yr})$ divided by its annual production $(\mathrm{kg} / \mathrm{kW} \cdot \mathrm{yr})$. The annual costs are the sum of yearly payment of CAPEX at the defined discount rate, yearly OPEX and cost of electricity used within the year, that is the price per $\mathrm{kWh}$ multiplied by the load factor and the total hours in a year. On the other hand, the total production of hydrogen in a year can be calculated by the multiplication between efficiency $(\mathrm{g} / \mathrm{kWh})$, load factor and the total hours in a year.

By running the financial model and registering the dependent variable $\left(\mathrm{H}_{2}\right.$ cost) for combinations of key input data (independent variables) that varied within certain intervals, it was possible to build a large matrix of possible outcomes and use it to adjust a linear regression, as given by Equation (1).

The analysis of such regression assisted the understanding of the relative importance of each input factor in the calculation of green $\mathrm{H}_{2}$ cost. The linear regression yielded the following expression:

$$
y=3.49-1.15 \times 10^{-2} f+1.38 \times 10^{-3} c+5.08 \times 10^{-2} p-1.31 \times 10^{-1} e
$$

where:

$$
\begin{aligned}
& y=\text { cost of green } \mathrm{H}_{2}(\mathrm{US} \$ / \mathrm{kg}) ; \\
& f=\text { electrolyser plant factor }(\mathrm{p} . \mathrm{u}) ; \\
& c=\text { electrolyser CAPEX (US\$/kW); } \\
& p=\text { electricity price (US } \$ / \mathrm{MWh}) ; \\
& e=\text { efficiency of the electrolysis (kg/MWh). }
\end{aligned}
$$

In addition to the cost of production, the price of hydrogen sold in Europe would depend also on the transport of such molecule. Internal transport costs in Brazil will depend on the location of the plant where the hydrogen is produced and processed into a derivative such as ammonia which is easier to transport. The choice of venue would be influenced primarily by the availability of renewable resources, fresh water, and the proximity to a port terminal where it is possible to transport ammonia. For those reasons, a candidate location would be Bahia (a Brazilian state), specifically near the port Aratu, just north of the State 
capital Salvador. It is one of the two ports in Brazil that are authorized to export ammonia and is near areas with great wind and solar potential (Figure 4).

In the state of Bahia there are places with low water availability. Thus, a study over the exact place to install the plant would be needed. Considering such location, the internal transport cost has little impact on the final price of the hydrogen.

The transport of Hydrogen from Brazil to Europe has its own complexity. Due to hydrogen's low energy density, transportation requires either high pressure compression (350 to 700 bars) or liquefaction at $-253^{\circ} \mathrm{C}$. Both options are energy-intensive, not very practical, and not economical for large distance transport. A possible option would be to use ammonia $\left(\mathrm{NH}_{3}\right)$ as a liquid carrier since it has a 50\% higher volumetric energy density than liquid hydrogen and liquifies more easily at $-33^{\circ} \mathrm{C}$ or with pressure less than 10 bar [13].

Green ammonia can also be used as shipping fuel, given its flexibility to work either with fuel cells or existing diesel or dual-fuel engines [14], and thereby contribute to significantly reducing the carbon footprint of the transport of $\mathrm{NH}_{3}$.

According to [15], the cost of converting hydrogen to ammonia should add roughly US\$ $1 / \mathrm{kgH}_{2}$ whereas long-distance travel of liquid ammonia could add another US\$ $0.2 / \mathrm{kgH}_{2}$. Thus, a first estimate for the final $\mathrm{H}_{2}$ cost in Europe, in the form of liquid ammonia, would be in the range of US $\$ 3.0$ to 3.7 per $\mathrm{kg}$.

Once the hydrogen derivative reaches the import terminal, it needs to be distributed for final use. According to [15], the cost of extracting and purifying the hydrogen at the point of end use, in the case of ammonia, would be equivalent to US $\$ 1.5 / \mathrm{kgH}_{2}$. It, however, could be directly used by the final customer, such as the chemical industry, without reconverting it back to hydrogen. Thus, the cost of distribution would be considerably lower, at US\$ $0.4 / \mathrm{kgH}_{2}$ [15].

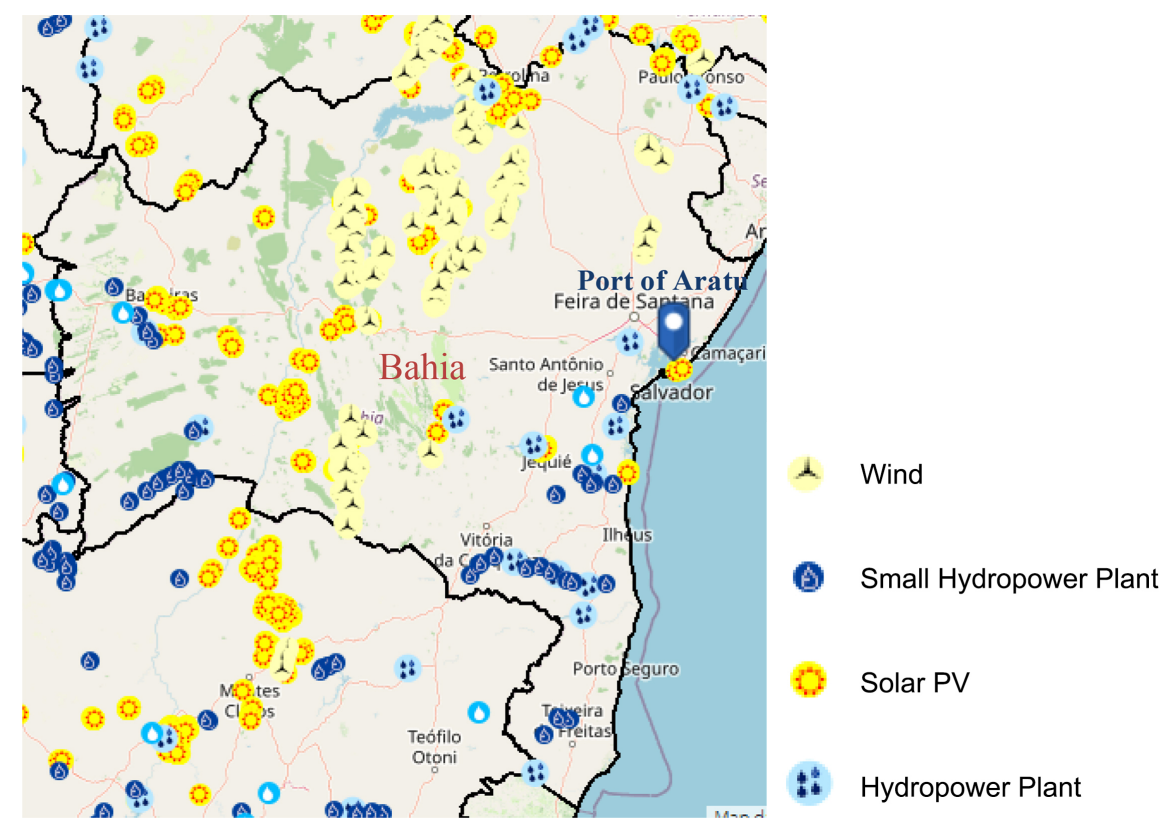

Figure 4. State of Bahia showing electricity generation assets and the Port of Aratu [12]. 


\section{Additional Factors}

In addition to offering a cheap renewable energy, Brazil has other attributes that would support the development of an internal hydrogen market and the prospects of becoming an important supplier to Europe. They are:

1) A cheap source of green hydrogen could be competitive for various sectors in the Brazilian economy, creating an internal market:

a) Brazil is a major exporter of agricultural produce and an importer of fertilizers. In 2019 the country imported US\$ 2.4 billion worth of nitrogen-based fertilizers, mostly in the form of urea [16]. A cheaper hydrogen feedstock could enable a local production of competitive green fertilizers, replacing the need to import such products. That substitution would be advantageous to the economy, especially if small-scale, distributed electrolysis technologies evolve, because they would avoid internal logistical difficulties that increase costs to farmers.

b) Given the country's large export activity and dependency on road transportation, the Brazilian transportation sector is a large consumer of fossil fuels, being responsible for almost $80 \%$ of total diesel consumption in 2019 [5]. In this scenario green ammonia or hydrogen could play a vital role in reducing the sector's greenhouse gas emissions by replacing oil used in trucks and maritime vessels, if it became sufficiently cheap.

c) The hydrogen could also be used as a feedstock in the reduction of iron to produce steel and a source of heat in the production of cement [17]. Both industries could benefit from a cheap hydrogen produced in the country, replacing the fossil fuels that are used nowadays.

d) The large Brazilian production of biofuels, such as ethanol and biodiesel [18], could provide $\mathrm{CO}_{2}$ from the fermentation process that would be necessary to produce green methanol. With a cheap hydrogen, it would be possible to have a cheap methanol produced locally, reducing, or even eliminating the current need to import such product.

2) Geopolitical stability and an established democracy may be an advantage compared to other locations where green hydrogen could be produced, such as the Middle East and North or West Africa.

3) The potential to expand variable renewable energy production in the country is huge considering the availability of cheap land with abundant wind and solar resources. Also, the existence of a flexible and integrated national grid allows the energy to be generated far from the $\mathrm{H}_{2}$ plant.

4) Since Brazil produces most of the electricity from different types of renewables, there is a conducive environment for the construction of new renewable energy capacity. The mature wind and solar industries in Brazil have the resources to develop large projects given the acquired knowhow by the workforce [19] and the established supply chain. Also, there is a solid regulatory framework for large renewable projects, allowing large projects to be developed in short timeframes.

5) Between 1824 and 1969, nearly 250,000 Germans emigrated to Brazil, espe- 
cially in the South of the country [20]. Given that Germany is currently leading a national strategy for green hydrogen, Brazil may benefit from this historical diplomatic relationship and the fact that an estimated 1600 German companies are installed in Brazil, representing $8 \%-10 \%$ of the Brazilian Industrial GDP [21]. Furthermore, most of the member companies of the German Hydrogen Association have subsidiaries in Brazil and green hydrogen is already an important topic in the technical cooperation between the two countries.

\section{Conclusions}

The European Union has announced a strategy to develop a market for green hydrogen as part of the efforts to reduce greenhouse gas emissions. To implement this strategy, it is expected that green hydrogen will be also supplied by foreign countries with favorable conditions for production. Natural contestants are Northern African and Middle East countries that enjoy good primary resources and have a geographical advantage.

Brazil, however, can compensate the larger distance to Europe with other outweighing factors, such as the existence of a thriving internal market for renewable energy and the fact that renewable energy already is the cheapest source, as demonstrated by the electricity auctions [22] [23] [24]. This is partially explained by the benefit of plenty of flexible hydropower in the country, that compensates cheaply and effectively the variability of other renewable sources, thus contributing to lower integration costs. Another important aspect is that it is expected a near to $100 \%$ electrolyser plant factor based on PPA contractual agreements with renewable energy producers in the country.

The fact that Brazil is an agricultural powerhouse that currently imports nitrogen-based fertilizers and the massive exports of mining and agricultural products, both heavy users of oil-based maritime navigation, opens possibilities for an internal market for green hydrogen and derived products. This means that European imports of Brazilian green $\mathrm{H}_{2}$ could trigger a large internal market build-up in Brazil with the potential to sustainably develop the local economy with positive externalities to the environment.

\section{Conflicts of Interest}

The authors declare no conflicts of interest regarding the publication of this paper.

\section{References}

[1] European Comission (2020) Communication from the Commission to the European Parliament, the Council, the European Economic and Social Committee and the Committee of the Regions: A Hydrogen Strategy for a Climate-Neutral Europe. European Union, Brussels.

[2] Oxford Institute for Energy Studies (2020) European Union Hydrogen Strategy. https://www.oxfordenergy.org/wpcms/wp-content/uploads/2020/07/EU-HydrogenStrategy.pdf 
[3] Federal Ministry for Economic Affairs and Energy (2020) The National Hydrogen Strategy. https://www.bmbf.de/de/nationale-wasserstoffstrategie-9916.html

[4] Brazilian Institute of Geography and Statistics (2020) Países. https://paises.ibge.gov.br/\#/dados/brasil

[5] Empresa de Pesquisa Energética (2020) Brazilian Energy Balance 2020: Year 2019. Empresa de Pesquisa Energética, Rio de Janeiro.

[6] Câmara de Comercialização de Energia Elétrica (2020) Resultado Consolidado dos leilões.

https://www.ccee.org.br/portal/faces/acesso_rapido_header_publico_nao_logado/bi $\underline{\text { bliote- }}$

ca_virtual?tipo=Resultado\%20Consolidado\&assunto=Leil\%C3\%A3o\&_afLoop $=247$ 70518076979\&_adf.ctrl-state=14rgdvz3oa_184\#!\%40\%40\%3F_afrLoop\%3D2477051 8076979\%26tipo\%3DResultado\%

[7] Bloomberg New Energy Finance (2019) Results-Climatescope 2019. https://global-climatescope.org/results

[8] Operador Nacional do Sistema Elétrico (2020) Dados da Geração Eólica. http://www.ons.org.br/Paginas/resultados-da-operacao/boletim-geracao-eolica.aspx

[9] Operador Nacional do Sistema Elétrico (2020) Energy Generation. http://www.ons.org.br/Paginas/resultados-da-operacao/historico-da-operacao/gerac ao_energia.aspx

[10] Vale (2020) Energia. http://www.vale.com/esg/pt/Paginas/Energia.aspx

[11] Energy Sector Management Assistance (2020) Green Hydrogen in Developing Countries. World Bank, Washington DC.

[12] Agência Nacional de Energia Elétrica (2020) SIGEL-Mapa dos Empreendimentos de Geração de Energia Elétrica. https://sigel.aneel.gov.br/portal/home/index.html

[13] The Royal Society (2020) Ammonia: Zero-Carbon Fertiliser, Fuel and Energy Store. Policy Briefing, The Royal Society, London.

[14] Ash, N. and Scarbrough, T. (2019) Sailing on Solar: Could Green Ammonia Decarbonise International Shipping? Environmental Defense Fund, London.

[15] International Energy Agency (2019) Future of Hydrogen. International Energy Agency, Paris.

[16] Ministério da Indústria, Comércio Exterior e Serviços (2020) Comex StatExportação e Importação Geral. http://comexstat.mdic.gov.br/pt/geral

[17] Bloomberg New Energy Finance (2020) Hydrogen Economy Outlook. Bloomberg New Energy Finance, city.

[18] International Energy Agency (2020) How Competitive Is Biofuel Production in Brazil and the United States?

https://www.iea.org/articles/how-competitive-is-biofuel-production-in-brazil-and-t he-united-states

[19] International Renewable Energy Agency (2019) Renewable Energy and Jobs: Annual Review 2019. International Renewable Energy Agency, Masdar City.

[20] Brazilian Institute of Geography and Statistics (2020) Brasil: 500 anos de Povoamento. https://brasil500anos.ibge.gov.br/territorio-brasileiro-e-povoamento/alemaes.html

[21] Ministry of Foreign Affairs (2020) Federal Republic of Germany. http://www.itamaraty.gov.br/en/ficha-pais/6014-federal-republic-of-germany

[22] Mastropietro, P., Batlle, C., Barroso, L.A.N. and Rodilla, P. (2014) Electricity Auc- 
tions in South America: Towards Convergence of System Adequacy and RES-E Support. Renewable and Sustainable Energy Reviews, 40, 375-385.

https://doi.org/10.1016/j.rser.2014.07.074

[23] Rudnick, H., Barroso, L.A., Moreno, R., Ferreira, R. and Pereira, E. (2017) Facilitating the Integration of Renewables in Latin America: The Role of Hydropower Generation and Other Energy Storage Technologies. IEEE Power \& Energy Magazine, 15, 68-80. https://doi.org/10.1109/MPE.2017.2708862

[24] Maurer, L.T. and Barroso, L.A. (2011) Electricity Auctions: An Overview of Efficient Practices. World Bank Studies, Washington DC.

https://doi.org/10.1596/978-0-8213-8822-8 